\title{
Working
}

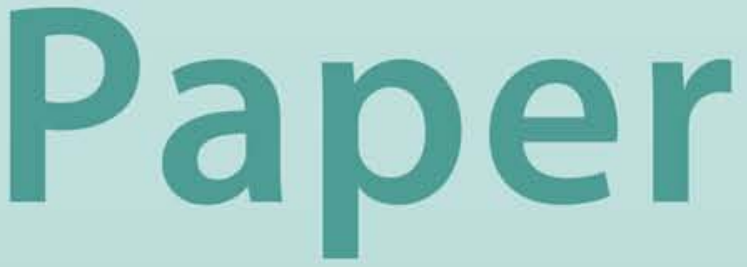


The Effects of Exchange Rate Change on the Trade Balance in Croatia

\author{
Tihomir Stučka
}




\title{
IMF Working Paper
}

Office of the Executive Director for Armenia, Bosnia and Herzegovina, Bulgaria, Croatia, Cyprus, Georgia, Israel, the former Yugoslav Republic of Macedonia, Moldova, Kingdom of the Netherlands, Romania and Ukraine

\section{The Effects of Exchange Rate Change on the Trade Balance in Croatia}

Prepared by Tihomir Stučka ${ }^{1}$

Authorized for distribution by Jeroen J. Kremers

April 2004

\begin{abstract}

\section{This Working Paper should not be reported as representing the views of the IMF.}

The views expressed in this Working Paper are those of the author(s) and do not necessarily represent those of the IMF or IMF policy. Working Papers describe research in progress by the author(s) and are published to elicit comments and to further debate.
\end{abstract}

A reduced-form model approach was used to estimate the trade balance response to permanent domestic currency depreciation. For this purpose, long-run and short-run effects were estimated, using three modeling methods along with two real effective exchange rate measures. On average, a 1 percent permanent depreciation improves the equilibrium trade balance by between 0.94 percent and 1.3 percent. The new equilibrium is established after approximately 2.5 years. Evidence of the J-curve is also found. Overall, in the light of the results obtained, it is questionable whether permanent depreciation is desirable to improve the trade balance, taking into account potential adverse effects on the rest of the economy.

JEL Classification Numbers: F30, F42, F14

Keywords: J-curve, trade balance, transitional economies

Author's E-Mail Address: tstucka@imf.org

\footnotetext{
${ }^{1}$ Tihomir Stučka is Advisor to the Executive Director of the IMF for Armenia, Bosnia and Herzegovina, Bulgaria, Croatia, Cyprus, Georgia, Israel, the Former Yugoslav Republic of Macedonia, Moldova, Kingdom of the Netherlands, Romania, and Ukraine. This paper has been published previously as a Croatian National Bank Working Paper No. W-11 (October 2003).
} 
Contents Page

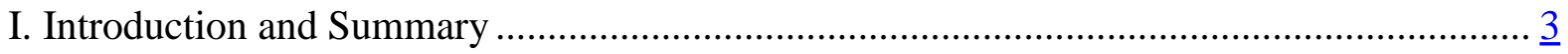

II. Literature Review ...................................................................................... 4

III. Real Exchange Rate and Merchandise Trade Development in Croatia........................... $\frac{7}{9}$

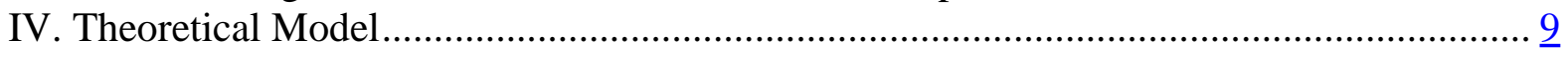

V. Applied Econometric Models .......................................................................... 11

VI. Data Description .......................................................................................... $\frac{13}{13}$

A. Technical Data Description............................................................................. $\frac{13}{15}$

B. Econometric Characteristics of the Data ........................................................... $\frac{15}{16}$

VII. Empirical Results ................................................................................ $\frac{16}{17}$

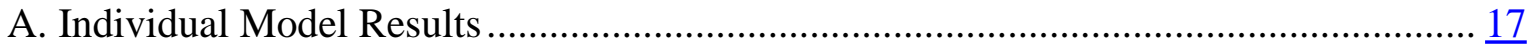

B. Interpretation and Summary of Results....................................................... $\frac{22}{24}$

VIII. Policy Implications .................................................................................. $\frac{24}{24}$

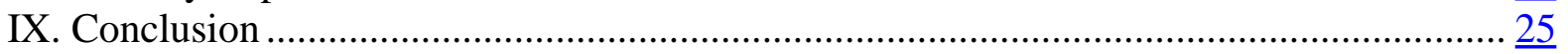

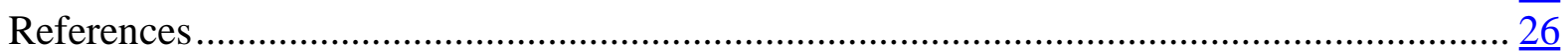

Tables

1. Augmented Dickey-Fuller and Phillips-Perron Test Results for Nonstationarity of

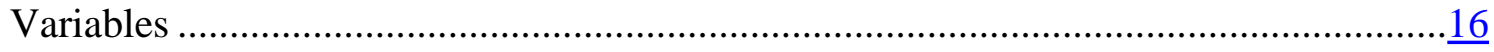

2. Producer Price Index Version Model: Test for Cointegration ........................................17

3: Consumer Price Index Version Model: Test for Cointegration ........................................19

4. Elasticity of Trade Balance with Respect to Eeal Effective Exchange Rate (q), Domestic

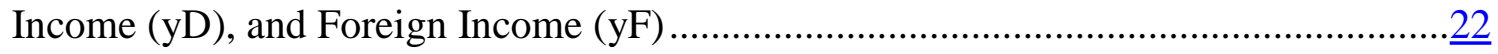

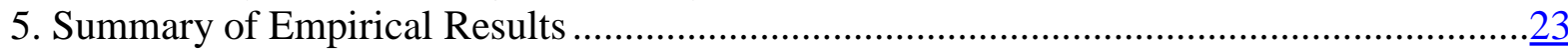

Figures

1. Trade Balance and Real Effective Exchange Rate (PPI based) ......................................... $\underline{8}$

2. Trade Balance and Real Effective Exchange Rate (CPI based) ....................................... $\underline{8}$

3. Impulse Response: Pesaran, Shin, and Smith Model (PPI) ......................................... 18

4. Impulse Response: Pesaran, Shin, and Smith Model (CPI) .........................................19

5. Impulse Response: ARDL(IV) - PPI.............................................................

6. Impulse Response ARDL(IV) - CPI............................................................... $\frac{20}{21}$

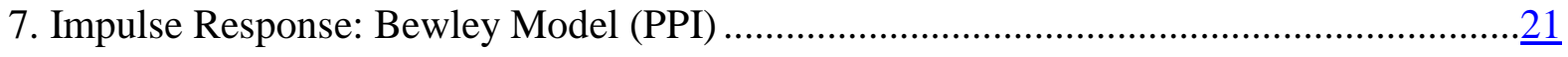

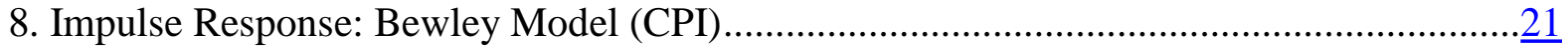




\section{INTRODUCTION AND SUMMARY}

The main component of Croatia's considerable current account deficit is the merchandise trade deficit. The merchandise trade deficit, in turn, is a result of stagnating exports and increasing imports over the last three years. In order to improve the trade balance, two approaches to changing the country's competitiveness are at the authorities' disposal. The internal approach relies on supply-side policies, such as influencing labor productivity or wages by, for example, curbing inflation, decreasing taxes (e.g. producers' share in the social contribution tax or the profit tax) or relaxing rigid labor market conditions. Alternatively, the external approach consists of devaluing/depreciating the currency. The public debate in Croatia on alleviating the merchandise deficit is split between advocates of nominal exchange rate devaluation/depreciation on the one side, and advocates of maintaining the managed floating exchange rate policy, on the other side. So far, however, a formal quantitative estimate of the long-run and short-run impacts of exchange rate changes on the merchandise trade balance is lacking. Closing this gap is the motivation for this paper.

Quantifying the short-run and long-run responsiveness of the merchandise trade balance to exchange rate changes is important to economic policy for several reasons. First, it establishes whether there is a stable long-run relationship between the exchange rate and the merchandise trade balance. If such a stable long-run relationship does not exist, then depreciating the exchange rate does not seem to be a reasonable way to improve the country's competitiveness on a long-term basis. Second, if a long-run relationship does exist, then it is necessary to establish whether depreciation is likely to lead to a net improvement of the trade balance in the long-run. Third, quantifying the extent of the trade balance improvement would be desirable, since doing so would enable us to weigh the trade balance benefits against the costs of permanent depreciation. Fourth, the estimate of the short-run dynamics provides information regarding the immediate and medium-run impacts of exchange rate changes on the trade balance. More specifically, the question here is whether depreciation has an adverse short-run impact on the merchandise trade balance. If it does, it seems reasonable to estimate the persistence and extent of the adverse effect. This is usually an empirical question, and in the literature it is referred to as the J-curve effect. Fifth, the results presented may contribute to further insights into the international transmission of changes in economic activity and prices. Sixth, in a broader sense, the estimates may also provide some information regarding the impact of expenditure-reducing policies, both monetary and fiscal, on the domestic trade balance. Seventh, it might encourage further analysis of the impact of substantial government foreign lending on the trade balance and the current account in general. Eighth, the results might eventually play a role in evaluating the appropriateness of an asymmetric central bank intervention policy with respect to an alternative such as the introduction of a crawling-peg exchange rate policy in order to support a permanent depreciation of the domestic currency.

The responsiveness of the merchandise trade balance to exchange rate changes is evaluated in a traditional two-country, imperfect-substitution model. The trade balance is approximated by aggregated flows of Croatia's six major trading partners. They account, on average, for over 55 percent of its total trade. The real effective exchange rate is modeled using the 
consumer price index (CPI) and the producer price index (PPI), often referred to as competitiveness measures. Domestic and foreign income are proxied by GDP. The period under observation runs from the first quarter of 1994 to the second quarter of 2002. Three modeling techniques and two competitiveness measures are employed to obtain more robust results. This is undertaken bearing in mind that Croatia is a transition country with only short time series available and a dynamic trading environment characterized by many outliers.

The estimated response of the trade balance to depreciation embodies a weighted average result. This is due to the foreign income variable aggregated across six major trading partners and the fluctuations that are averaged out in the real effective exchange rate. In other words, the trade balance response incorporates the asymmetric response of trade flows to exchange rate changes across the six countries. Hence, the nonexistence of a long-run relationship or Jcurve effect on an aggregated level can mean that, on average, it does not hold for Croatia. However, on a disaggregated level it could still be valid for some countries. The aggregated approach was used, since policy-makers are more interested in single, averaged outcomes than in case-by-case information. Also, the disaggregated data are generally subject to larger measurement errors than aggregated data. In addition, disaggregated functions are more likely to be misspecified than aggregated ones (Grunfeld and Griliches, 1960; and Aigner and Goldfeld, 1974). At the same time, the definition of the aggregated foreign income variable also has problems.

Evidence is found of a long-run relationship between the trade balance and its arguments. There appears to be a positive long-run trade balance elasticity with respect to the exchange rate ranging between 1.5 and 2.1. The long-run domestic income elasticity is lower than the foreign income elasticity. It seems that, on average, the J-curve effect does exist in Croatia. Furthermore, it is estimated that, on average, the short-run adverse effect of depreciation on the trade balance lasts about one quarter, during which the trade balance deteriorates by around 2.0 percent. In addition, it seems to take the trade balance about 2.5 years to reach a new equilibrium level, improving, on average, between 0.9 percent and 1.3 percent compared with the old equilibrium.

The paper is organized as follows. Section II contains a brief literature review. Section III describes the exchange rate and merchandise trade developments in Croatia and provides a definition of, and reasons behind, the J-curve effect. Section IV presents the theoretical model, followed by a brief description, in Section V, of the modeling techniques employed. Section VI describes the technical and econometric characteristics of the data. Section VII presents the empirical results and their interpretation and comparison with estimates in the literature. Section VIII provides some implications for policymakers stemming from the empirical results. Section IX concludes.

\section{LiterATURE REVIEW}

The short-run and long-run relationships between the trade balance and exchange rate have been subject to many empirical studies. Here a brief overview is provided of methodologies and results of the literature for developed and emerging economies. This will demonstrate 
that the variety of results, often for identical countries, may stem from empirical evidence being extracted from different time periods and different methodologies.

Developed countries, especially the United States, have received most of the attention in this field of research. In their seminal paper, Rose and Yellen (1989) employ disaggregated, bilateral trade data and do not find support for the J-curve effect nor evidence of a long-run relationship in the case of U.S. data for the period 1960 to 1985. Neither did BahmaniOskooee and Brooks (1999), analyzing bilateral disaggregated U.S. trade data with respect to six major trading partners using the ARDL approach developed by Pesaran and Shin (1997) and Pesaran, Shin and Smith (1996) find evidence of a J-curve effect. However, they did report a significant long-run relationship between the trade balance and the exchange rate, indicating that a real depreciation of the U.S. dollar has a favorable effect on the U.S. trade balance. Shirvani and Wilbratte (1997) use a VECM approach for the United States with respect to G7 countries. They find evidence of a reversed L-curve effect. Demirden and Pastine (1995) employ Sim's VAR methodology and demonstrate in a simple empirical example that feedback effects in a flexible exchange rate environment may be significant, resulting in a J-curve effect.

Felmingham (1988) tests the J-curve proposition by fitting an unrestricted distributed lag to Australian data for the period 1965 to 1985 . He also cannot find evidence for the J-curve phenomenon. On the other side, Marwah and Klein (1996) find evidence of an S-curve for both Canada and the United States utilizing disaggregated data in an IV and OLS regression for the period 1977 to 1992 . According to their results, the trade balance initially declines after depreciation, followed by a trade balance improvement - the typical J-curve effect. However, after several quarters there seems to be a tendency for the trade balance to worsen. This $\mathrm{S}$ - curve finding is reminiscent of the $\mathrm{S}$-shaped response of the trade balance to changes in terms of trade mentioned in Backus, Kehoe and Kydland (1994).

Furthermore, Bahmani-Oskooee and Alse (1994) tested 41 developed and less developed countries for the existence of cointegration and the J-curve effect applying the Engle-Granger two-step procedure. The results indicated that the trade balance and real effective exchange rate are co-integrated for only fourteen countries. In the countries exhibiting cointegration, there was some evidence of the J-curve effect. Gupta-Kapoor and Ramakrishnan (1999) analyzed the impact of the yen appreciation on Japanese trade balance data with respect to seven major trading partners employing a VECM. The estimated impulse response function indicated the existence of a J-curve for Japan. Jung and Doroodian (1998) obtained similar results for Japan. They applied the Shiller lag model to first differences finding support for the J-curve effect. In conclusion, evidence seems to suggest that the J-curve is an empirical phenomenon, i.e. it may or may not be found in a given country.

The preponderance of evidence, so far, suggests that the United States does not exhibit such short-run import and exports elasticities leading to a J-curve effect. Support for a stable longrun relationship between the U.S. trade balance and its determinants are mixed. Japan, on the other hand, is an example of trade elasticities that do result in the J-curve phenomenon. 
Recently, an upsurge of research has occurred relating to less developed countries, predominantly emerging Asian markets. Baharumshah (2001) employs an unrestricted VAR model for the bilateral trade balances of Thailand and Malaysia with the United States. and Japan for the period 1980 to 1996. He finds support for a stable and positive long-run relationship between trade balance and the exchange rate. The evidence on the short-run response of the trade balance supporting the J-curve effect is mixed. A delayed J-curve seems to apply to Thai data, whilst no support for the J-curve was found in Malaysian data. In addition, Bahmani-Oskooee and Kantipong (2001) tested on disaggregated data the J-curve between Thailand and her main trading partners Germany, Japan, Singapore, United Kingdom, and the United States for the period 1973 to 1997. They find evidence of the Jcurve in bilateral trade with the U.S. and Japan only.

Upadhyaya and Dhakal (1997) test the effectiveness of devaluation on the trade balance for eight developing countries (Colombia, Cyprus, Greece, Guatemala, Mexico, Morocco, Singapore, and Thailand) applying the methodology proposed by Wickens and Breusch (1988). Their empirical finding is contradictory to Baharumshah's findings regarding Thailand. They provide evidence that seems to suggest that only in the Mexican case devaluation improve the trade balance in the long-run. Bahmani-Oskooee (2001) investigated the long-run response of Middle Eastern countries' trade balances to devaluation by applying the Engle-Granger and Johansen-Juselius cointegration methodology. The evidence suggests that there exist a favorable long-run effect of a real depreciation on the trade balance for all seven countries (Bahrain, Egypt, Jordan, Morocco, Syria, Tunisia, and Turkey). In the case of Morocco, this opposes the results obtained by Upadhyaya and Dhakal. Wilson (2001) examined the relationship between the real trade balance and the real exchange rate for bilateral merchandise trade between Singapore, Korea and Malaysia with respect to the United States and Japan. No evidence of a J-curve effect was found, with the exception of Korean trade with the United States. In the case of Turkey, Akbostanci (2002) finds support for a favorable long-run relationship between the exchange rate and the trade balance. The generalized impulse response function indicates in the short-run an S-shaped trade balance response to devaluation. This view with respect to the positive long-run relationship is supported in Bahmani-Oskooee (2001). However, Kale (2001) obtains conflicting results, providing evidence of a negative long-run impact of devaluation on the trade balance. In the short-run Kale finds evidence of a delayed J-curve effect.

Research related to the relationship between the trade balance and the exchange rate in CEEC countries is still scarce. Hacker and Hatemi (2002) looked at disaggregated bilateral data between the Czech Republic, Hungary, and Poland with respect to Germany. They found evidence of a positive long-run relationship between the trade balance and the exchange rate for all three countries. The Czech Republic and Poland seem to possess characteristics that lead to the J-curve effect. This is not the case with Hungary.

Overall, the evidence suggests that the J-curve is not an empirical regularity. For some countries, the J-curve effect predominantly applies, for some it does not. The evidence supports the existence of a favorable stable long-run relationship between the trade balance and the exchange rate, with a few exceptions, most notably the United States. 


\section{Real Exchange Rate And Merchandise Trade Development in Croatia}

In this section, the development of the current account deficit is described, as well as its origins. This will locate the merchandise trade balance in terms of the Croatian current account. It is continued by clarifying the two versions of the exchange rate variable applied later in the analysis. Finally, the meaning of the long-run and the short-run trade balance responses to exchange rate changes are described briefly.

The current account deficit in Croatia reached its peak in 1997 (12.5 percent of GDP). In subsequent years, a sustained improvement took place, only to be reversed starting in 2002. At the end of 2002, the current account deficit deteriorated, according to preliminary data, to a five-year high of about 6.9 percent of GDP. The main generator of the substantial deficit is the merchandise trade balance. More precisely, the merchandise deficit rests on stagnating exports and propulsive imports.

Compared to other transition countries, Croatia did not fully succeed in adjusting its export structure to new demand, whilst strong imports were necessary to satisfy the domestic demand for consumption and, recently, investment. At the same time, flourishing net tourism income as well as net current transfer inflows based on workers' remittances traditionally cushion the negative balance.

However, in spite of tourism income and remittances offsetting partially the negative impact of the merchandise deficit, a healthier merchandise trade balance would result in less demand for foreign financing and would overall provide improved competitiveness and non-seasonal employment. Net tourism receipts, although increasing at a strong rate in the past few years, generally are vulnerable to reversals in "tourism fashion" and to security crises (e.g. Kosovo and Iraq crises). In addition, tourism has generated, so far, to a large extent only seasonal employment due to the limited season (Kraft and Stučka 2001). Hence, strong rates of net tourism income growth and worker's remittances do not suffice to compensate for weak performance of the merchandise trade balance.

In Figures 1 and 2, the normalized, seasonally adjusted real effective exchange rate (REER) is plotted based on Croatia's six major trading partners together with the real trade balance (TB) expressed as the export-to-import ratio. An increase in the exchange rate denotes a depreciation and vice versa. 
Figure 1. Trade Balance and Real Effective Exchange Rate (PPI based)

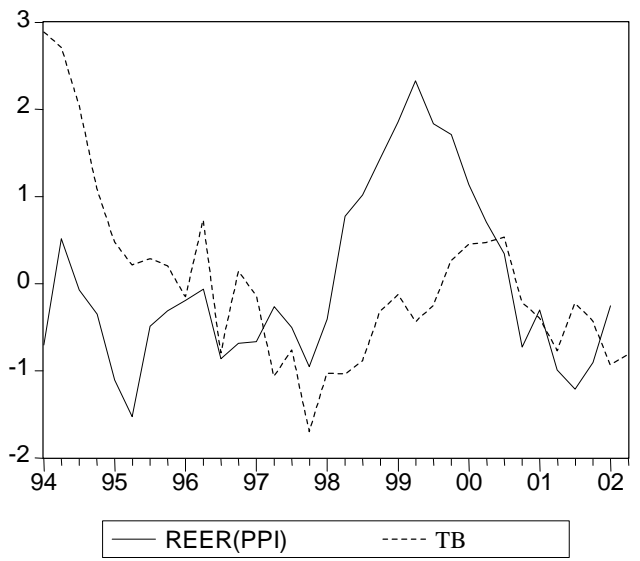

Figure 2. Trade Balance and Real Effective Exchange Rate (CPI based)

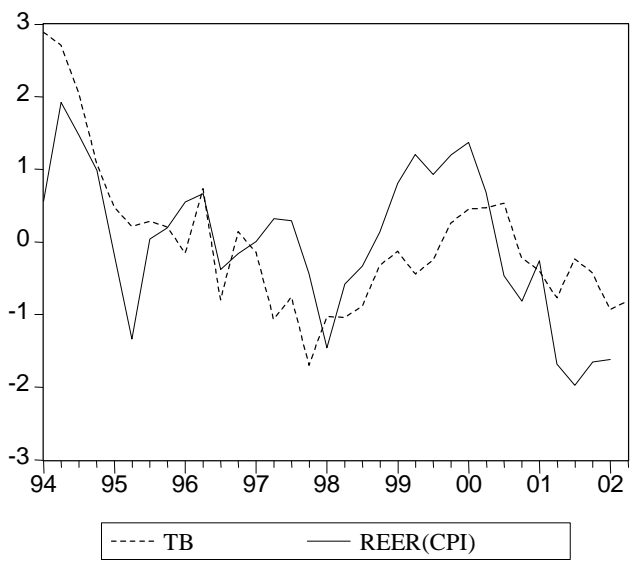

Sources: Croatian Bureau of Statistics; Croatian National Bank; and author's calculations

For the purposes of this paper, the real effective exchange rate is calculated with respect to six trading countries based on the consumer price index (CPI) and the producer price index (PPI). The real effective exchange rate based on CPI and PPI are often regarded as measures of a country's competitiveness.

The CPI contains information of prices on final traded and non-traded goods, including imports. It does not contain, as opposed to the PPI, information regarding intermediate goods, raw materials or capital goods purchased by producers. Also, it is subject to many distortions embodied in e.g. administrative prices and levied excise duties. However, since labor input is often priced in line with CPI growth one could regard it as a useful indicator for the cost of production (Marsh and Tokarick, 1994).

The producer price index, on the other hand, is often used as a proxy for domestic export prices. It is designed to measure price changes in the domestic industry's total output, however, regardless of the destination of output. The PPI index includes prices of intermediate goods, raw materials and capital goods and from the perspective of production theory is similar to the export price index (Altermann, 1997). Since the PPI target is domestic production, imports are excluded.

The real effective exchange rate based on CPI depreciated less than the PPI exchange rate between 1998 and 2000. This is due to the strong growth of prices of services, tobacco products and beverages. In the latter two cases, price increases can be related to increases in excise duties.

The weak performance of the trade balance led to proposals for an external approach to improving the country's competitiveness. There are two aspects of trade balance responsiveness to changes in the exchange rate - the long-run and the short-run response. The long-run describes the steady state between the new level of the exchange rate and the trade 
balance. Once the steady state has been attained, the dynamic responses are worn out and the system is in a new equilibrium.

The initial, short-run deterioration of the trade balance as a reaction to depreciation is known in the literature as the J-curve. The name stems from the pattern of the trade balance caused by contracts outstanding during the exchange rate change. The J-curve occurs due to sticky domestic-currency prices of exports, which are subject to medium term contracts. So, export prices in foreign currency fall and at the same time import prices in terms of domestic output increase. After a certain time lag export and import volumes adjust to new prices and the trade balance starts to improve. Put differently, the J-curve represents a possible transition path from the old equilibrium level to the new equilibrium level.

The time lag occurs due to several reasons such as the recognition lag, decision lag, delivery lag, replacement lag and production lag (Junz and Rhomberg, 1973). The recognition lag is the time needed for the markets to realize that competitiveness conditions have changed. The decision lag occurs due to the time necessary to establish new business connections and orders. This entails building up new supplier-customer relationships that both parties are reluctant to break. The delivery lag involves the necessary time to deliver the orders after which payments are undertaken and the trade flow published. The replacement lag accounts for the replacement of inventories, out-dated equipment to wear out or to be drawn down before being replaced. The production lag is the time needed to undertake modifications in supply capacities and supply patterns. In other words, producers might choose to wait until they become convinced that the currency reflects a definite trend and a profit opportunity exists to warrant the expense of reallocating resources, which are costly to reverse.

In conclusion, the J-curve effect represents a specific transition path to a new equilibrium level due to permanent exchange rate changes. This phenomenon occurs as certain lags arise due to new competitiveness circumstances on the demand and supply side.

\section{THEORETICAL MODEL}

We start by defining the model, which follows the standard "two-country" imperfect substitutes model as specified in Goldstein and Kahn (1985) and Rose and Yellen (1989). In this model, imports, exports and the trade balance refer to the merchandise component. Key assumptions of the models are that neither imports nor exports are perfect substitutes for domestic goods, so that finite elasticities for demand and supply can be estimated for most traded goods. The volume of imports demanded domestically, $\mathrm{M}_{\mathrm{d}}$, and the quantity of imports demanded by the rest of the world, $\mathbf{M}^{*}$, are given by equations (1) and (2):

$$
\begin{aligned}
& M_{d}=f_{1}\left(Y, P_{M}, P\right), \frac{\partial M_{d}}{\partial Y}>0, \frac{\partial M_{d}}{\partial P_{M}}<0, \frac{\partial M_{d}}{\partial P}>0 \\
& M_{d}^{*}=f_{2}\left(Y^{*} e, P_{M}^{*}, P^{*}\right), \frac{\partial M_{d}^{*}}{\partial Y^{*} e}>0, \frac{\partial M_{d}^{*}}{\partial P_{M}^{*}}<0, \frac{\partial M_{d}^{*}}{\partial P^{\prime}}>0
\end{aligned}
$$


where $\mathrm{Y}$ is domestic income, $\mathrm{P}_{\mathrm{M}}$ the domestic currency price paid by domestic importers and $\mathrm{P}$ denotes the overall domestic price level, i.e. the price of all domestically produced goods. In equation (2), $\mathrm{Y}^{*}$ represents foreign income, e the exchange rate expressed as the domestic currency price of foreign exchange, $\mathrm{P}^{*}{ }_{\mathrm{M}}$ denotes the foreign currency price paid by domestic importers and $\mathrm{P}^{*}$ the overall foreign price level. In other words, the demanded quantity is a function of the level of money income in the importing region, the imported goods' own price and the price of domestic substitutes. Since we deal with aggregated data, the assumption is that inferior goods or domestic complements are excluded ${ }^{2}$. This implies that domestic income and foreign income elasticity are assumed positive as well as the cross-price elasticities of demand. The own-price elasticities of demand are assumed to be negative. Furthermore, it should be noted that the demand variables are represented only by current income rather then permanent and transitory income.

Usually in such models homogeneity of the demand function is assumed, so that the consumer does not suffer from money illusion - demand will remain constant when doubling money income and prices. Hence, this homogeneity assumption is expressed by dividing the explanatory variables on the right hand side by $\mathrm{P}$. This way arguments of the demand function are expressed in real terms - real income and relative prices of import to domestically produced goods. As a result of these modifications we can re-write equations (1) and (2) as

$$
\begin{aligned}
& M_{d}=f_{1}\left(Y_{r}, R P_{M}\right), \frac{\partial M_{d}}{\partial Y_{r}}>0, \frac{\partial M_{d}}{\partial R P_{M}}<0 ; Y_{r}=\frac{Y}{P}, R P_{M}=\frac{P_{M}}{P} \\
& M_{d}^{*}=f_{2}\left(Y_{r}^{*}, R P_{M}^{*}\right), \frac{\partial M_{d}}{\partial Y^{r}}>0, \frac{\partial M_{d}}{\partial R P_{M}^{*}}<0 ; Y_{r}^{*}=\frac{Y^{*}}{P^{*}}, R P_{M}^{*}=\frac{P_{M}^{*}}{P^{*}}
\end{aligned}
$$

Since the relative price of imports is equivalent to the foreign currency price of foreign exports adjusted for the exchange rate we may define the relative price of imports as

$$
R P_{M}=\frac{P_{M}}{P}=\frac{e P_{X}^{*}}{P}=\frac{e P^{*}}{P} \frac{P_{X}^{*}}{P^{*}}=Q \frac{P_{X}^{*}}{P^{*}}=Q p_{x}^{*},
$$

where $\mathrm{p}_{\mathrm{x}}{ }_{\mathrm{x}}$ represents real foreign currency price of exports, whilst $\mathrm{q}$ denotes the real exchange rate defined in such a way that an increase in q refers to a depreciation of the domestic currency (eq. 6).

\footnotetext{
${ }^{2}$ If we would deal with disagregated data then those aforementioned assumption would not need to be plausible
} 
$Q=\frac{e P^{*}}{P}$

Finally, the quantity of imports supplied by the rest of the world to the domestic country, i.e. the rest of the world export supply function, and the quantity of exports domestically supplied to the rest of the world are given in equations (7) and (8):

$$
\begin{aligned}
& X_{S}=f_{3}\left(P_{X}, P\right) \\
& X_{S}^{*}=f_{4}\left(P_{X}^{*}, P^{*}\right)
\end{aligned}
$$

where $\mathrm{P}_{\mathrm{x}}$ is the domestic currency price received by domestic exporters and vice versa.

In equilibrium, conditions (9) and (10) determine the demand and supply conditions for both regions:

$$
\begin{aligned}
& M_{d}=X_{S}^{*} e \\
& M_{d}^{*}=X_{S}
\end{aligned}
$$

Hence, defining the trade balance as

$$
T B=p_{x} M_{d}^{*}-Q p_{x}^{*} M_{d}
$$

and solving for levels of domestic exports and imports as well as the relative price level of imports as a function of the real exchange rate we obtain the partial reduced form of the domestic trade balance in (12):

$T B=f\left(Y_{r}, Y_{r}^{*}, Q\right), \frac{\partial T B}{\partial Y_{r}}<0, \frac{\partial T B}{\partial Y_{r}^{*}}>0, \frac{\partial T B}{\partial Q}>0$

Hence, we expect real foreign income and real exchange rate to be positively related to the trade balance and domestic income negatively related to the trade balance.

\section{ApPlied Econometric Models}

As mentioned earlier, the results related to the long-run and short-run relationships between the trade balance and its arguments are often dependent upon the observation period and the econometric technique employed. Therefore, in order to obtain robust results we utilize three different econometric techniques - the ARDL approach developed by Pesaran, Shin, and Smith (1995), the Bewley type (1979) ARDL approach also mentioned in Wickens and Breusch (1988), and the ARDL with instrumental variables approach developed by Pesaran and Shin (1997). The choice of techniques was based on two main objectives. First, to 
determine the existence of a co-integrating relationship among the variables in the light of low power and contradictory results of the unit root tests. And second, to avoid the simultaneity bias inherent in reduced form models.

The Pesaran, Shin, and Smith (1995) method (PSS) avoids the classification of variables as I(1) and I(0) by developing bands of critical values which identifies the variables as being stationary or non-stationary processes. Therefore, previous unit root testing of the variables is unnecessary. This approach involves two stages. In the first stage, the null hypothesis of the non-existence of the long-run relationship is tested (13):

$$
\begin{aligned}
& \Delta t b_{t}=\alpha+\sum_{i=1}^{n} \beta_{i} \Delta t b_{t-i}+\sum_{i=1}^{n} \gamma_{i} \Delta q_{t-i}+\sum_{i=1}^{n} \delta_{i} \Delta y_{t-i}^{D}+\sum_{i=1}^{n} \lambda_{i} \Delta y_{t-i}^{F}+\theta_{1} t b_{t-1}+\theta_{2} q_{t-1} \\
& +\theta_{3} y_{t-1}^{D}+\theta_{4} y_{t-1}^{F}+\varepsilon_{t} \\
& H_{0}: \theta_{1}=\theta_{2}=\theta_{3}=\theta_{4}=0 \\
& H_{1}: \theta_{1} \neq \theta_{2} \neq \theta_{3} \neq \theta_{4} \neq 0
\end{aligned}
$$

The relevant statistic to test (14) is the F-test or the Wald-test. Since the asymptotic distribution of these two tests is non-standard Pesaran, Shin, and Smith (1996) calculated two sets of appropriate critical values. One set assumes all variables are $\mathrm{I}(0)$ and the other set assumes that all variables are I(1). If the calculated statistic is above the upper limit of the band, then the null hypothesis is rejected. In that case, the variables are co-integrated. If the statistic is below the lower band, then the variables are not co-integrated and the null hypothesis is not rejected. The area within the band is the inconclusive area. In that case, no statement regarding cointegration can be made. Once cointegration is determined, the second stage involves defining the error-correction term. This is undertaken in an analogous way to the second step of the Engle-Granger two-step procedure. Incorporating the long-run and short-run terms into the model allows a more efficient estimate of the short-run coefficients.

Direct estimation of the equilibrium response described by Bewley (1979) and Wickens, Breusch (1988) makes it possible to estimate the long-run coefficients of the real exchange rate directly. The estimation of the differenced terms will capture the shot-run dynamics. This way the J-curve effect can be tested. To determine the long-run response of the trade balance to depreciation, we specify the following model

$$
y_{t}=\sum_{i=1}^{m} \alpha_{i} y_{t-1}+\sum_{i=0}^{n} \beta_{i} x_{t-1}+e_{t}
$$

Subtracting from both sides $\left(\sum_{i=1}^{m} \alpha_{i}\right) y_{1}$ and then re-arranging $\mathrm{x}_{\mathrm{t}}$ 's we obtain 
$y_{t}=-\lambda \sum_{i=1}^{m} \alpha_{i} \Delta y_{t-1}+\lambda\left(\sum_{i=0}^{n} \beta_{i}\right) x_{t}-\lambda \sum_{i=0}^{n} \beta_{i} \Delta x_{t-1}+\lambda e_{t}$

where

$$
\lambda=\frac{1}{1-\sum \alpha_{i}}
$$

In equation (16), the term $\lambda\left(\sum_{i=0}^{n} \beta_{i}\right)$ represents the long-run coefficient. Hence, estimating

(17) by TSLS is equivalent to estimating (15) by OLS (Bewley (1979), p. 361). We estimate (2) by employing $\Sigma \mathrm{y}_{\mathrm{t}-\mathrm{n}}, \Sigma \mathrm{x}_{\mathrm{t}-\mathrm{n}}$ and a constant as instruments. The application of TSLS removes the simultaneity problem. In addition, standard errors are directly estimated and identical to those obtained by utilizing the asymptotic expansion. A major problem, however, is the existence of a mean for the distribution of the long-run response in finite samples. Thus, it is to be expected that extreme estimates might arise in empirical work. The coefficient on the lagged dependent variable is a major factor in determining the magnitude of the bias in the long-run response (Bewley, Fiebig (1990)). The advantage of this approach is the amount of degrees of freedom. However, there is the possibility of a theoretically inconsistent model due to the exclusion of seemingly significant explanatory variables. Nevertheless, we used this approach as a benchmark model.

Pesaran, Shin (1997) also developed an autoregressive distributed lag model approach with instrumental variables. This approach is a mixture between the aforementioned approach developed by Pesaran, Shin and Smith (1995) and Bewley's (1979) regression approach (see equation (14)). As opposed to the "delta"-method described above, this approach uses instrumental variables. It has good small sample properties and is likewise robust to the data generating process of the variables (difference stationary or stationary). As already described in Bewley's approach, the instruments should contain all independent variables with the exception of current and lagged differences in the dependent variable, which should be replaced by its lagged levels.

\section{DAta DESCRIPTION}

\section{A. Technical Data Description}

We proceed by describing the estimated period, data sources, potential problems associated with the data and the methodology used for estimating the real effective exchange rate for the purpose of this paper.

The estimated period of the model is 1994(1) to 2002(1), using quarterly data. Previous periods have not been employed due to unreliable data. More specifically, before 1994 GDP data do not exist. Also, in the fourth quarter of 1993 Croatia introduced a stabilization 
program, followed by a currency change. The goal was to tame inflation and to stabilize the exchange rate. This represents a major structural break in the series. Hence, starting from 1994 seems to be the "lowest possible denominator" from which to model the data.

Data on merchandise exports, imports and trade direction is taken from the Croatian Bureau of Statistics (CBS) reports. Those data contain recent corrections for trade in the shipbuilding industry. The methodological break in 2000 did not have a significant impact on export and import data on a quarterly basis. It merely changed the distribution within a quarter, whereas spillover effects from one quarter to another are not significant. The break originates from the implementation of a new customs document (single administrative document), which introduced a completely new approach to data processing in the CBS. Up to that point, all declarations that were submitted to the Customs Office in a particular month were processed irrespective of the date when the customs duties were levied. Therefore, data for each month comprised a number of declarations from previous periods. After January 2000, only declarations approved in the customs office during the reference month are processed. Furthermore, we use revised data on domestic GDP published by the CBS.

Data on PPI indices and real GDP data for the main Croatian trading partners - Austria, France, Germany, Italy, Slovenia, and the United Kingdom - are obtained from the IMF's International Financial Statistics CD (February 2003). In spite of its trade importance for Croatia, we do not include Bosnia in our model due to data unavailability. Croatian PPI and $\mathrm{CPI}$ indices are from the CNB database, as well as the seven bilateral nominal exchange rates, which are listed below.

The merchandise trade balance is defined as the ratio of exports to imports. This way one can perform nominal and real trade balance analysis without additional data manipulation. In addition, it neatly solves the problem of using the log-form of a trade deficit.

Data on the real effective exchange rate represent author's estimates since the official rate published by the CNB comprises information from trade in visibles and invisibles (invisibles being predominantly tourism receipts). The basis for the official rate is the foreign exchange structure in the balance of payments. Hence, it does not represent the appropriate variable for the purpose of this paper. We calculate the real effective exchange rate as follows:

$q_{t}=100 \prod_{i}\left(S_{t} \frac{P_{i t}}{P_{t}}\right)^{w_{i}}$,

$\mathrm{i}=$ Euro (Austria, Germany, Italy, France), British sterling, Slovenian tolar

$\mathrm{t}=1994 \mathrm{q} 1,1994 \mathrm{q} 2 \ldots .2002 \mathrm{q} 1$

$w_{i}=\sum_{1996 \mathrm{q} 1}^{2000 \mathrm{q} 4} \frac{\mathrm{T}^{\mathrm{i}}}{T^{\text {total }}} \times 1 / 20$

where $\mathrm{q}$ is the real effective exchange rate, $\mathrm{P}$ is the producers' price index, $\mathrm{S}$ is the nominal bilateral exchange rate, $\mathrm{i}$ represents the specific trading partner, $\mathrm{T}$ stands for the value of 
merchandise trade and $w$ denotes total merchandise trade weights for the six currencies, which are fixed at the average trade weight for each trading partner from 1996 to 2000. This time span was chosen because it represents the period after hostilities ended in Croatia. The result of the model represents the weighted average of the effective exchange rate fluctuation because the domestic currency is appreciating against one currency and simultaneously appreciating against another. If we want to focus on trade with respect to individual countries then bilateral data should be taken into account. The foreign income variable is based on a weighted average of the indexes of real GDP for six main trading partners using variable export shares as weights. Again, the weight is fixed as an average for 1996 to 2000.

All variables are seasonally adjusted and in log-form. The import to export ratio, domestic real GDP and the real effective exchange rate are seasonally adjusted using the TRAMOSEATS ARIMA model. This was not the case for the foreign demand proxy, which did not pass the test diagnostics for the TRAMO-SEATS model due to a large amount of outliers; i.e. the ARIMA model could not fit all of the observations. Hence, we seasonally adjusted the composite index of foreign demand utilizing the model X12, which provided a better fit.

\section{B. Econometric Characteristics of the Data}

We continue by examining the stationarity requirement of the five variables $\left(\mathrm{TB}, \mathrm{Q}^{\mathrm{PPI}}, \mathrm{Q}^{\mathrm{CPI}}\right.$, $\left.\mathrm{Y}^{\mathrm{D}}, \mathrm{Y}^{\mathrm{F}}\right)$. Here, two issues need to be discussed. First is the issue of technical stationarity test results. The second relates to the economic rationale of the stationarity results.

In light of the short time series, two tests are performed to obtain some degree of robustness. In particular, we employ the augmented Dickey-Fuller (ADF) test and the Phillips-Perron (PP) test. The distribution theory supporting the Dickey-Fuller test assumes that the error in the regression is identical and independently distributed. Hence, autocorrelation and heteroskedasticity should not be present in the estimated residuals. When utilizing the ADF test we follow the procedure based on the methodology by Dolado, Jenkinson and SosvillaRivero (1990) as described by Enders (1995). The PP test is a generalization of the ADF procedure that relaxes the restrictions of autocorrelation and heteroskedasticity by undertaking a non-parametric correction of the t-test. However, Monte Carlo simulation (Schwert, 1989) has shown that Phillips type test have poor size properties. Table 1 reports the test results for the five variables, both in levels and in first-differences. 
Table 1. Augmented Dickey-Fuller and Phillips-Perron Test Results for Nonstationarity of Variables

\begin{tabular}{||lccc|cc|}
\hline Trade balance (TB) & -0.601 & $(4)$ & -2.967 & -1.839 & -2.953 \\
Real effective exchange rate CPI (Q_cpi) & -1.800 & $(0)$ & -2.956 & 5.355 & -2.953 \\
Real effective exchange rate PPI (Q_ppi) & -2.956 & $(5)$ & -2.975 & -1.919 & -2.956 \\
Domestic GDP (Yd) & -1.996 & $(0)$ & -2.953 & -1.934 & -2.953 \\
Foreign GDP (Yf) & -3.491 & $(3)$ & -3.580 & -0.914 & -2.956 \\
\hline B. Variables in differences & & & & & \\
\hline d(TB) & -5.143 & $(0)$ & -2.956 & -5.284 & -2.956 \\
d(Q_cpi) & -5.519 & $(0)$ & -2.959 & -5.540 & -2.959 \\
d(Q_ppi) & -5.231 & $(0)$ & -2.959 & -5.262 & -2.959 \\
d(Yd) & -4.220 & $(0)$ & -2.956 & -4.202 & -2.956 \\
d(Yf) & -2.558 & $(5)$ & -2.980 & -4.708 & -2.959 \\
\hline \hline
\end{tabular}

Notes:all variables are in natural logarithms, $d$ is the first difference operator, ADF is the Augmented DickeyFuller test, PP is the Phillips-Perron test, CV denotes MacKinnon critical values for rejecting the unit root hypothesis

Source: author's calculations

Both tests consistently suggest that the trade balance, real effective exchange rate PPI based, domestic GDP and foreign GDP are non-stationary in levels, although, there seem to be borderline cases. The real effective exchange rate CPI based is non-stationary in levels according to the ADF test and stationary according to the PP test. Four variables are stationary in first-differences according to both tests. The foreign demand variable is an exception since it did not pass the ADF test, but is stationary according to the PP test.

As opposed to the test results, economic reasoning has difficulties in explaining some of the stationarity results obtained. It is hard to imagine that the real effective exchange rate is a difference or trend stationary process. Indeed, a constantly depreciating or appreciating currency does not coincide with real world facts. Yet, when dealing with short time series, as is the case with transition countries, it is plausible that those series seem to have a unit root. Therefore, we prefer to utilize several techniques in order to ensure robustness of results. More specifically, we first utilize the procedure proposed by Pesaran, Shin, and Smith (1996) to investigate the cointegration relationship without differentiating between $\mathrm{I}(1)$ and $\mathrm{I}(0)$ variables. We will then proceed by applying an ARDL model with instrumental variables. In addition, the approach put forward by Bewley (1979) as well as Wickens and Breusch (1988) is used.

\section{EMPIRICAL RESULTS}

As previously mentioned, we attempt to obtain robust estimates by employing two measures of competitiveness (CPI and PPI based real effective exchange rate) and three modeling techniques. In this section, on the one hand, we refer to the long-run relationships, and on the 
other to the short-run dynamic models and depict the impulse response for a permanent 1 percent shock to the exchange rate. The first part of this section provides a brief overview of the empirical results starting with the Pesaran, Shin, and Smith (1996) approach (PSS), explaining in detail the estimation procedure, which is then applied to the estimates. We continue with the ARDL instrumental variable approach (ARDL(IV)) and the Bewley type ARDL approach (BEW) estimates. In the second part of this section, we provide a summary of empirical results, their interpretation and their comparison to results in the literature. In addition, we discuss the problems associated with the approach used.

\section{A. Individual Model Results}

Recall that the method developed by Pesaran, Shin, and Smith (1996) involves two stages. In the first stage, we test for cointegration regardless of the unit root characteristics of the variables. A significant F-test or Wald test indicates cointegration among the variables. We deal first with the PPI version model.

Table 2. Producer Price Index Version Model - Test for Cointegration

\begin{tabular}{|c|c|c|c|}
\hline \multicolumn{4}{|c|}{ Null Hypothesis: } \\
\hline F-statistic & 12.17667 & Probability & 0.000178 \\
\hline Chi-square & 48.70668 & Probability & 0 \\
\hline \multicolumn{4}{|c|}{$\begin{array}{l}\text { Notes: Critical value bounds of the Wald statistic with intercept and no trend } \\
\text { at } 95 \text { percent } \mathrm{I}(0) 17.69 \text { and } \mathrm{I}(1) 23.34 \text {. Hence, the null hypothesis is rejectec }\end{array}$} \\
\hline \multicolumn{4}{|c|}{$\begin{array}{l}\text { Critical value bounds of the F statistic with intercept and no trend at } 95 \\
\text { percent } \mathrm{I}(0) 2.85 \text { and } \mathrm{I}(1) 4.049 \text {. Hence, the null hypothesis is rejected. }\end{array}$} \\
\hline
\end{tabular}

The test results are above the upper-bound critical value indicating a rejection of the null hypothesis of no cointegration. Hence, the long-run relationship of the PPI version model can be defined as ${ }^{3}$

$t b=1.96 q^{P P I}-3.78 y^{D}+4.87 y^{F}$

Adjusted $\mathrm{R}^{2}=0.83$, F-statistic $=10.81, \mathrm{LM}$ test:1.66 ( $\left.\mathrm{p}=0.23\right)$, Reset test:2.32 ( $\left.\mathrm{p}=0.15\right)$

Once the long-run is established, we proceed in the spirit of Engle and Granger (1987) by specifying the error-correction term to obtain the short-run dynamics. We shock the dynamic model with a permanent change in the exchange rate, and leave the other two income variables constant. The short-run effect of the permanent 1 percent depreciation is represented in the form of an impulse response diagram. The diagram does not contain references to a certain time period since the impulse should relate to a reaction of the dynamic model, which is supposed to be time neutral, i.e. not associated to any specific year. For this reason, we also exclude dummy variables and the constant term from the dynamic

${ }^{3}$ small letters denote seasonally adjusted variables in log-form 
model since on one hand, they take account of very specific events (outliers) and contain a multitude of other information, which are not picked-up by the defined variables. This way we obtain the impulse response of the trade balance as shown in Figure 3.

Impulse response model - PSS approach (PPI version)

$$
\begin{aligned}
\Delta \mathrm{tb}_{\mathrm{t}}= & -0.53 * \mathrm{EC}_{\mathrm{t}-1}-0.82 \Delta \mathrm{q}_{\mathrm{t}-1}^{\mathrm{PPI}}-1.06 \Delta \mathrm{q}_{\mathrm{t}-2}^{\mathrm{PPI}}+4.00 \Delta \mathrm{q}_{\mathrm{t}-3}^{\text {PPI }} \\
& -0.25 \Delta \mathrm{tb}_{\mathrm{t}-1}+0.12 \Delta \mathrm{tb}_{\mathrm{t}-2}-0.09 \Delta \mathrm{tb}_{\mathrm{t}-3}-0.33 \Delta \mathrm{tb}_{\mathrm{t}-4}
\end{aligned}
$$

where EC represents the error correction term.

Figure 3: Impulse response: Pesaran, Shin, and Smith Model (PPI)

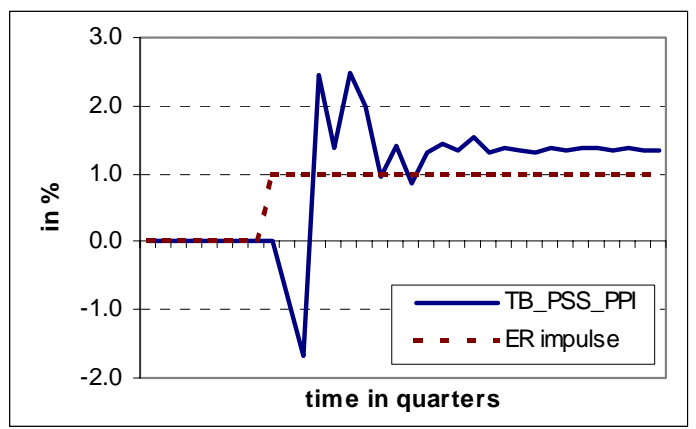

Source: author's calculations

Notes: PPI denotes the producer price index; TB denotes the trade balance; and ER denotes the exchange rate

According to the impulse response outcome after a permanent depreciation, the trade balance deteriorates initially by a total amount of 2.5 percent . The length of the adverse effect is two quarters. Ten quarters after the shock the new equilibrium level is established in line with new market conditions. The new equilibrium level is according to this model 1.4 percent above the old equilibrium level.

The procedure for estimating the CPI version model corresponds to the aforementioned method. In Table 3, we present the joint $F$ test and Wald test for no cointegration regarding the variables involved. 
Table 3: Consumer Price Index Version Model - Test for Cointegration

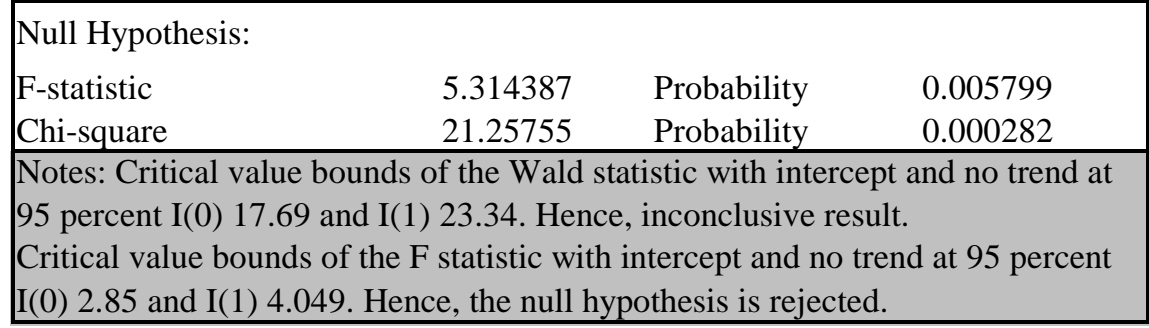

Taking into account both test outcomes, the results from Table 1 seem to indicate that there exists cointegration among the arguments of the trade balance model. Hence, the long-run relationship in the CPI version model would take the form

$\log t b=2.25 \log q^{C P I}-2.70 \log y^{D}+2.95 \log y^{F}$

Adjusted $\mathrm{R}^{2}=0.48$, F-statistic $=3.18, \mathrm{LM}$ test:3.53 $(\mathrm{p}=0.03)$, Reset test:0.162 $(\mathrm{p}=0.69)$

The short-run dynamic response of the trade balance according to (23) is presented in Figure 4 .

Impulse response model - PSS approach (CPI version)

$$
\begin{aligned}
\Delta \mathrm{tb}_{\mathrm{t}}= & -0.73 \mathrm{EC}_{\mathrm{t}-1}-2.47 \Delta \mathrm{q}_{\mathrm{t}-1}^{\mathrm{CPI}}-1.63 \Delta \mathrm{q}_{\mathrm{t}-2}^{\mathrm{CPI}}+2.66 \Delta \mathrm{q}_{\mathrm{t}-3}^{\mathrm{CPI}}-1.34 \Delta \mathrm{y}_{\mathrm{t}-1}^{\mathrm{D}} \\
& -3.09 \Delta \mathrm{y}_{\mathrm{t}-2}-0.04 \Delta \mathrm{tb}_{\mathrm{t}-1}+0.21 \Delta \mathrm{tb}_{\mathrm{t}-2}-0.14 \Delta \mathrm{tb}_{\mathrm{t}-3}-0.34 \Delta \mathrm{tb}_{\mathrm{t}-4}
\end{aligned}
$$

Figure 4. Impulse Response: Pesaran, Shin, and Smith Model (CPI)

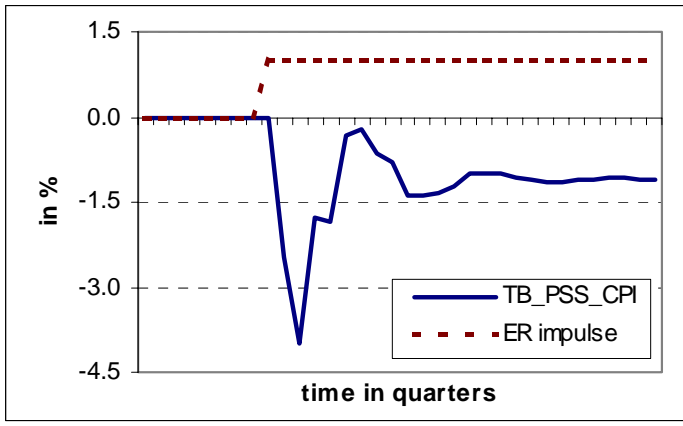

Source: author's calculations

After a permanent depreciation the trade balance at first deteriorates by 10.1 percent in total. The length of the adverse effect is four quarters. Fifteen quarters after the shock the new equilibrium level is established. However, this new equilibrium level is according to this model 1.05 percent below the old equilibrium level. To sum up, two versions of the model in a PSS approach yield some very different results. Although both versions provide evidence that a co-integrating relationship does exist, the impulse response outcome is in opposite 
directions. In the PPI version, the new equilibrium is above the old one, whilst the contrary is the case in the CPI version.

The ARDL approach using instrumental variables combines the short-run and the long-run in the same model. However, since the variables are modeled by instrumental variables the problem of simultaneity bias is avoided, and one need not test for exogeneity of the variables. The long-run relationship for the PPI version is provided in (24), whilst the CPI version of the model is represented in (25)

$\log t b=1.00 \log q^{P P I}-3.54 \log y^{D}+3.66 \log y^{F}$

Adjusted $\mathrm{R}^{2}: 0.98$, LM test: $1.72(\mathrm{p}=0.28)$, Reset test: $0.76(\mathrm{p}=0.41)$

$\log t b=2.09 \log q^{C P I}-3.38 \log y^{D}+4.42 \log y^{F}$

Adjusted $\mathrm{R}^{2}: 0.96$, LM test: $1.96(\mathrm{p}=0.18)$, Reset test: $0.33(\mathrm{p}=0.57)$

The impulse response of the trade balance according to (26) and (27) for the CPI and PPI version is given in Figure 5 and 6, respectively.

Impulse response model: ARDL(IV) approach (PPI and CPI version)

$$
\begin{aligned}
& \Delta \mathrm{tb}_{\mathrm{t}}=-0.99 \mathrm{q}^{\mathrm{PPI}}{ }_{\mathrm{t}}-0.41 \Delta \mathrm{q}_{\mathrm{t}-1}^{\mathrm{PPI}}-2.00 \Delta \mathrm{q}_{\mathrm{t}-1}^{\mathrm{PPI}}-0.83 \Delta \mathrm{q}_{\mathrm{t}-2}^{\mathrm{PPI}} \\
& +2.13 \Delta \mathrm{q}_{\mathrm{t}-3}^{\mathrm{PPI}}-3.53 \mathrm{y}_{\mathrm{t}}+0.32 \Delta \mathrm{y}_{\mathrm{t}}{ }^{\mathrm{D}}-1.47 \Delta \mathrm{y}_{\mathrm{t}-1}^{\mathrm{D}} \\
& +3.64 y_{t} F_{t}-1.76 \Delta y_{t} F_{t}-11.63 \Delta y_{t-1} F+0.34 \Delta t_{t}+0.13 \Delta t_{t-1} \\
& \Delta \mathrm{tb}_{\mathrm{t}}=2.09 \mathrm{q}^{\mathrm{CPI}}{ }_{\mathrm{t}}-2.61 \Delta \mathrm{q}^{\mathrm{CPI}}{ }_{\mathrm{t}}-1.21 \Delta \mathrm{q}_{\mathrm{t}-1}^{\mathrm{CPI}}-3.39 \mathrm{y}_{\mathrm{t}}+1.06 \Delta \mathrm{y}_{\mathrm{t}}{ }_{\mathrm{t}} \\
& +1.45 \Delta \mathrm{y}_{\mathrm{t}-1}^{\mathrm{D}}+4.42 \mathrm{y}_{\mathrm{t}} \mathrm{F}-6.73 \Delta \mathrm{y}_{\mathrm{t}}-9.63 \Delta \mathrm{y}_{\mathrm{t}-1}+0.62 \Delta \mathrm{tb}_{\mathrm{t}} \\
& +0.26 \Delta \mathrm{tb}_{\mathrm{t}-1}
\end{aligned}
$$

Figure 5. Impulse Response: ARDL(IV) - PPI

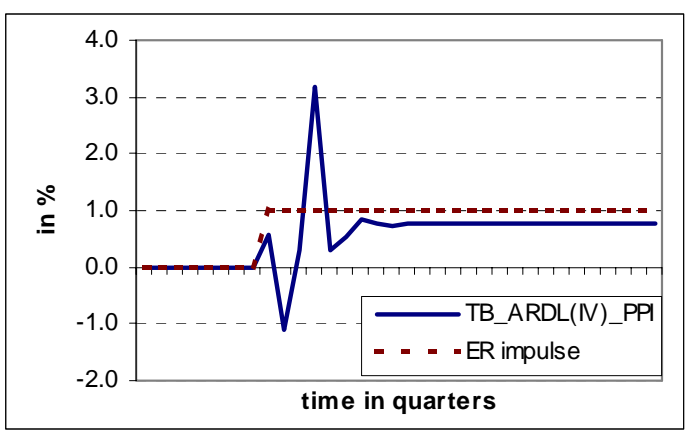

Source: author's calculations
Figure 6. Impulse Response ARDL(IV) - CPI

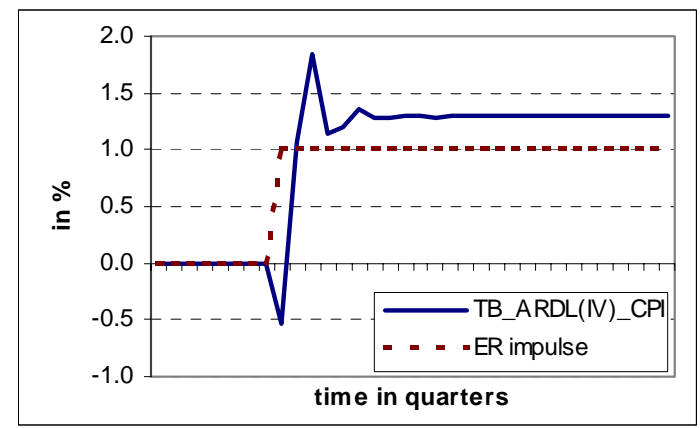

In both cases there seem to be signs of a J-curve effect. In the PPI version, we could interpret the impulse response as a delayed J-curve effect since the trade balance deteriorates with a 
lag of one quarter to the permanent depreciation. At the same time, the CPI version indicates a textbook example of the J-curve phenomena. In both cases, the time needed to achieve the new trade balance equilibrium is six quarters. The length of the adverse effect in both cases is one quarter. However, the models differ in the initial decrease in the trade balance and the extent of improvement of the new equilibrium level. In the PPI version the trade balance deteriorates by 0.5 percent and arrives at a new equilibrium 1.29 percent above the equilibrium before the permanent depreciation. In the CPI version the initial worsening of the trade balance amounts to 1.1 percent, whilst the new equilibrium is 0.75 percent above the old equilibrium level. The response difference between those two models could be explained by the different trends of the price indices. PPI inflation has been lower than CPI inflation; and hence, PPI based REER depreciation has been more pronounced than the CPI based REER. Therefore, for the same trade balance outcome and the same level of permanent depreciation the PPI based REER renders a lower response of trade flows.

The Bewley type ARDL approach focuses only on two variables, namely the trade balance and exchange rate. Equation (28) and (29) denote the impulse response model, which is illustrated diagrammatically in Figure (7) and (8).

Impulse response model

$$
\begin{aligned}
\mathrm{tb}_{\mathrm{t}}= & 1.39 \mathrm{q}^{\mathrm{PPI}}{ }_{\mathrm{t}}-6.84 \Delta \mathrm{q}_{\mathrm{t}-1}^{\mathrm{PPI}}-1.03 \Delta \mathrm{q}^{\mathrm{PPI}}{ }_{\mathrm{t}-2}+3.12 \Delta \mathrm{q}^{\mathrm{PPI}}{ }_{\mathrm{t}-3} \\
& -3.03 \Delta \mathrm{q}^{\mathrm{PPI}-4}-0.13 \Delta \mathrm{tb}_{\mathrm{t}-1} \\
\mathrm{tb}_{\mathrm{t}}= & 1.81 \mathrm{q}^{\mathrm{CPI}}{ }_{\mathrm{t}}-1.61 \Delta \mathrm{q}_{\mathrm{t}-1}^{\mathrm{CPI}}-0.63 \Delta \mathrm{q}_{\mathrm{t}-2}^{\mathrm{CPI}}+1.77 \Delta \mathrm{q}^{\mathrm{CPI}}{ }_{\mathrm{t}-3} \\
& -1.51 \Delta \mathrm{q}_{\mathrm{t}-4}^{\mathrm{CPI}}-0.29 \Delta \mathrm{tb}_{\mathrm{t}-1}-0.26 \Delta \mathrm{tb}_{\mathrm{t}-2}-0.02 \Delta \mathrm{tb}_{\mathrm{t}-3}-0.13 \Delta \mathrm{tb}_{\mathrm{t}-4}
\end{aligned}
$$

Figure 7. Impulse Response: Bewley Model (PPI)

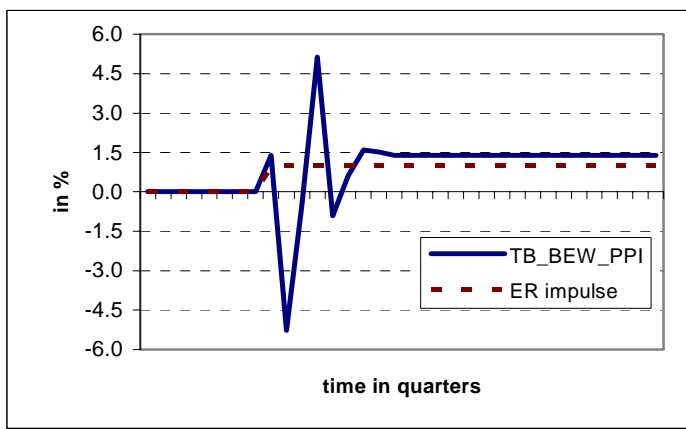

Source: author's calculations
Figure 8: Impulse Response: Bewley Model (CPI)

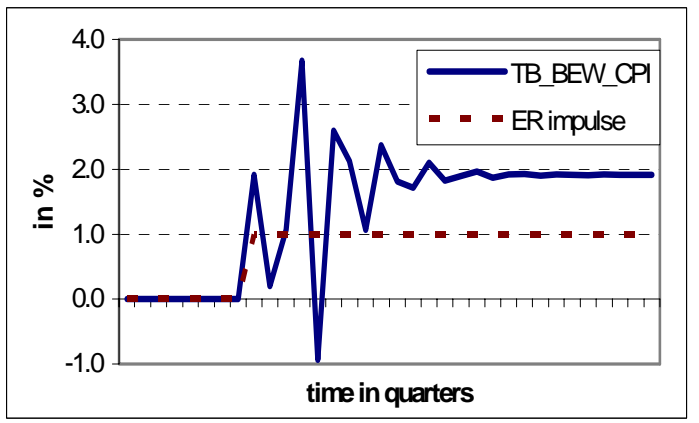

In the PPI version model there seems to be a delayed J-curve effect lasting for two quarters with an adverse impact on the trade balance amounting to a total of 5.8 percent . After eight quarters, the new equilibrium level is established at 1.41 percent above the old equilibrium. For the CPI version of the model there does not seem to be support for a J-curve effect. The 
new equilibrium level is reached after 15 quarters at 1.9 percent above the old equilibrium level.

\section{B. Interpretation and Summary of Results}

The signs of coefficients in all three models correspond to theoretical expectations (Table 4). Also, the estimates are reasonably consistent for both measures of domestic competitiveness. Overall, the CPI measure yields a moderately higher long-run elasticity of the trade balance with respect to the exchange rate compared to the PPI version. To be conservative we proceed by commenting on the averages presented in Table 4.

Table 4. Elasticity of the Trade Balance with Respect to the Real Effective Exchange Rate (q), Domestic Income (yD) and Foreign Income (yF)

\begin{tabular}{|l|cccc|c|}
\hline \multicolumn{2}{|c}{ LR coefficients } & Bewley & PSS & ARDL (IV) & average \\
\hline $\mathrm{q}$ & CPI based & 1.82 & 2.24 & 2.09 & 2.05 \\
& PPI based & 1.39 & 1.96 & 1.00 & 1.45 \\
\hline $\mathrm{yD}$ & CPI based & & -2.70 & -3.39 & -3.05 \\
& PPI based & & -3.78 & -3.54 & -3.66 \\
\hline $\mathrm{yF}$ & CPI based & & 2.94 & 4.42 & 3.68 \\
& PPI based & & 4.87 & 3.66 & 4.27 \\
\hline
\end{tabular}

Source: author's calculations

This elasticity depends upon the substitution effect, or put differently, the availability of domestic substitutes for imported goods. In addition, it seems that the elasticity of domestic income is lower than the elasticity of foreign income. This is consistent with income elasticity estimates in the majority of other countries. Yet, due to higher growth rates in Croatia compared to its six largest trading partners the net impact on the trade balance is likely to be negative. Croatia's full membership in CEFTA might reflect a structural break in terms of the trade balance responsiveness to exchange rate changes. However, we do not capture this effect directly since we mainly model EU countries. Needless to say, estimating the impact of trade with other CEEC countries would significantly improve our understanding of the effectiveness of devaluation since trade with those countries is on the rise. It seems that the long-run elasticity of the trade balance with respect to the exchange rate is on average between 1.45 and 2.05 , in terms of foreign income the elasticity is on average between 3.68 and 4.27, whilst domestic income exhibits an elasticity averaging between 3.05 and 3.66.

The results correspond to estimates presented in Hacker and Hatemi-J (2002) regarding some CEEC transitional countries. In their paper, the Czech and Polish long-run exchange rate elasticity with respect to German trade is 1.4 and 1.2, respectively. In addition, foreign income elasticity is above the domestic income elasticity. Bahmani-Oskooee and Brooks (2001) estimated the long-run exchange rate elasticities of the U.S. trade balance with respect to Japan (1.7), Germany (0.9) and the United Kingdom (0.8). Again, in most cases the foreign income elasticity is above the domestic income elasticity. 
Results regarding the effectiveness of a permanent exchange rate devaluation/depreciation are summarized in Table 5.

Table 5. Summary of Empirical Results

\begin{tabular}{|l|c|c|c|c|}
\hline \multicolumn{1}{|c|}{$\begin{array}{c}\text { Estimation } \\
\text { method }\end{array}$} & $\begin{array}{c}\text { Realtive position of } \\
\text { new long-run } \\
\text { equilibrium level }\end{array}$ & $\begin{array}{c}\text { Time for new } \\
\text { equilibrium in } \\
\text { quarters }\end{array}$ & $\begin{array}{c}\text { Length of J- } \\
\text { curve effect }\end{array}$ & $\begin{array}{c}\text { Extent of J- } \\
\text { curve effect }\end{array}$ \\
\hline BEW-CPI & 1.91 & 15 & 0 & 0.00 \\
BEW-PPI & 1.41 & 8 & 2 & -5.77 \\
PSS-CPI & -1.05 & 15 & 4 & -10.10 \\
PSS-PPI & 1.35 & 10 & 2 & -2.49 \\
ARDL(IV)-CPI & 1.29 & 6 & 1 & -0.52 \\
ARDL(IV)-PPI & 0.75 & 6 & 1 & -1.11 \\
\hline total average & $\mathbf{0 . 9 4}$ & $\mathbf{1 0}$ & $\mathbf{1 . 6 7}$ & $\mathbf{- 3 . 3 3}$ \\
average without & $\mathbf{1 . 3 4}$ & $\mathbf{9}$ & $\mathbf{1 . 2 0}$ & $\mathbf{- 1 . 9 8}$ \\
PSS_CPI & & & & \\
\hline
\end{tabular}

Source: author's calculations

On average, a permanent 1 percent depreciation of the domestic currency results in a 0.94 percent improvement of the trade balance. If we ignore the outlier among the estimates (PSS approach with CPI based exchange rate proxy), then the improvement of the trade balance amounts to 1.34 percent. On average, the new equilibrium is established after approximately 2.5 years. The average length of the adverse effect of permanent depreciation is moderately above one quarter. From a theoretical point of view, the speed of subsequent trade balance improvement would heavily depend also upon the credibility of a permanent depreciation. The increase of the trade balance as a consequence of the negative J-curve effect is estimated to be between 2.0 and 3.3 percent . This issue is mostly related to the responsiveness of import prices to exchange rate depreciation, as well as to the size of depreciation since foreign exporters can compensate price increases only to a certain degree. In addition, if a further unfavorable pass-through effect on exporters' prices exists, then the J-curve effect might be even more pronounced.

Naturally, in light of the short time series at disposal and the very dynamic trade environment characterized by numerous outliers the results should be treated with caution. A few models are somewhat susceptible to inclusion of dummy variables necessary to account for outliers. In addition, a single equation approach does have its drawbacks. That is, if there are more than two variables in a model, then up to n-1 linearly independent co-integrating vectors may exist. The assumption of one co-integrating vector, when in fact there is more than one vector, leads to inefficiency, since we can only obtain a linear combination of those vectors when a single equation is estimated. The problem might be even worse if the explanatory 
variables in the co-integrating relationship are not weakly exogenous, since then even if there is only one co-integrating vector the estimates will be potentially inefficient and misleading.

\section{POLICY IMPlications}

The results seem to suggest that improvement of the trade balance after a permanent devaluation/depreciation is very limited. A 1 percent permanent devaluation results in a new equilibrium level, which is 1.34 percent above the old equilibrium, at best. Also, the initial adverse effect in the shape of a J-curve phenomenon might be significant. Hence, before drawing conclusions from the estimated reduced form model one has to weigh trade balance benefits with potential unfavorable effects of a permanent depreciation. Here we shall briefly mention eight potential spillover effects of devaluation, which could have an adverse effect on the economy or neutralize the efforts of nominal depreciation with the aim to achieve real depreciation.

The first potential undesirable by-product is the pass-through of the exchange rate on inflation. This might lead to neutralization of nominal depreciation due to domestic price increase and consequently the tendency for the real exchange rate to appreciate.

The second possible adverse effect stems from high dependence of Croatian production and exports on imports, i.e. imported intermediate goods and raw materials. Hence, the increase in domestic producers' competitiveness evolving from real depreciation might be eroded by increases in import prices. Examples of such economies include Turkey (Kale (2001)) and Singapore (Abeysinghe, Yeok (1998)). Therefore, it should be analyzed whether products with a low imported input or vice versa dominate the commodity structure of exports.

The third possible adverse effect is that both increases in import prices and export prices may lead to a deterioration of domestic real income.

The fourth adverse effect is associated with the shift of resources from the non-tradable to the tradable sector. A further upsurge in the tradable sector productivity accompanied by wage increases might lead to a wage gap between the tradable and non-tradable sector. This might result in a wage spiral and/or a net increase in unemployment bearing in mind the existing exceedingly rigid labor market in Croatia. More precisely, it could be argued that increasing wages could lead to layoffs in the non-tradable sector at a rate exceeding the absorption capacity of the tradable sector.

The fifth adverse effect relates to the level of indexed debt in Croatia held by enterprises and households. The long history of high euroization in the economy led to a remarkable degree of debt indexed initially to the German mark and then the Euro. The distribution and structure of such debt should be taken into account in order to evaluate possible consequences of devaluation.

The sixth and last adverse effect, partly interconnected with the previous argument, is the concern that a strong, permanent depreciation might have a serious impact on public finances 
increasing the domestic currency cost of debt servicing. Measures to combat the considerable general government deficit, which is currently at around 5.5 percent of GDP might be put in serious risk. Additional heavy reductions in government spending to account for increased debt servicing costs would have severe consequences on the entire economy.

\section{COnClusion}

This paper attempts to estimate the impact of a permanent exchange rate depreciation on the merchandise trade balance employing a reduced form model. The model was estimated using three methods - the ARDL "delta" approach developed by Pesaran, Shin, and Smith (1996), the Bewley (1979) type ARDL model, and the ARDL instrumental variable approach described in Pesara and Shin (1997). Along with three modeling methods, the paper used two definitions of the real effective exchange rate to obtain robust results.

On average, a permanent 1 percent depreciation of the domestic currency results in an improvement of the trade balance between 0.94 percent and 1.3 percent . On average, the new equilibrium is established after approximately 2.5 years. The average length of the adverse effect of permanent depreciation is moderately above one quarter. This study finds evidence of the J-curve effect in Croatia. The increase of the trade balance deficit as a consequence of the J-curve effect is estimated to be between 2.0 percent and 3.3 percent . As a transition country, Croatia exhibits a dynamic trade environment characterized by many outliers. Consequently, results are somewhat susceptible to the inclusion of dummy variables. Nevertheless, the empirical results are consistent with the exception of one model. Overall, intuitively it seems unlikely that a permanent nominal depreciation of the domestic currency embodied in an asymmetric intervention policy a pegged exchange rate regime would have a net favorable effect on the entire economy, taking into account potential negative side effects.

There are several paths for further research. First, a VAR and/or VECM could be estimated to take full account of the feedback effects. Second, modeling bilateral trade data would certainly offset the possible mismeasurement regarding the shipbuilding trade data embedded in Croatian trade with Italy. In addition, an alternative modeling approach could utilize the disaggregated data according to standard international trade classification. Again, shipbuilding, as well as trade in oil derivatives could be separately treated, which might lead to different outcomes. 


\section{REFERENCES}

Abeysinghe, Tilak, and Tan Lin Yeok, 1998, "Exchange Rate Appreciation and Export Competitiveness. The Case of Singapore", Applied Economics, Vol. 30, pp. 51 - 55

Aigner, Dennis J., and Stephen M. Goldfeld, 1974, Estimation and Prediction from Aggregate Data When Agregates Are Measured More Accurately Then Their Components, Econometrica, Vol. 42, pp. 113 - 134

Akbostanci, Elif, 2002, "Dynamics of the Trade Balance: The Turkish J-curve", ERC Working Papers, 02/05

Altermann, Bill, 1997, “Are Producer Prices Good Proxies for Export Prices?”, Monthly Labor Review, October

Arize, Augustine, 1987, "The Supply and Demand for Imports and Exports in a Simultaneous Model", Applied Economics, Vol. 19, pp. 1233 - 1247

Baharumshah, Ahmad Z., 2001, "The Effect of Exchange Rate on Bilateral Trade Balance: New Evidence from Malaysia and Thailand", Asian Economic Journal, Vol. 15, No. 3, pp. $291-311$

Bahmani-Oskoee, Mohsen, and Alse, Janardhanan, 1994, "Short-Run Versus Long-Run Effects of Devaluation: Error-Correction Modeling and Cointegration", Eastern Economic Journal, Vol. 20, No. 4, Fall 1994, pp. 453 - 464

Bahmani-Oskoee, Mohsen, and Taggert J. Brooks, 1999, "Bilateral J-curve Between U.S. and Her Trading Partners", Weltwirtschaftliches Archiv, Vol. 135(1), pp. 156 - 165

Bahmani-Oskoee, Mohsen, 2001, "Nominal and Real Effective Exchange Rates of Middle Eastern Countries and Their Trade Performance", Applied Economics, Vol. 33, pp. $103-111$

Bahmani-Oskoee, Mohsen, and Kantiapong, Tatchawan, 2001, "Bilateral J-Curve Between Thailand and Her Trading Partners", Journal of Economic Development, Vol. 26, No. 2, December, pp. 107 - 117

Bewley, Ronald, 1979, "The Direct Estimation of The Equilibrium Response in a Linear Dynamic Model", Economics Letters 3, pp. 357 - 361

Bewley, Ronald, and Denzil, Fiebig, , 1990, "Why Are Long-Run Parameter Estimates So Disparate?", The Review of Economics and Statistics, pp. 345 - 349 
Briguglio, Lino, 1989, “The Impact of a Devaluation on the Maltese Trade Balance With Special Reference to the Price And Income Reversal Effects", Applied Economics, Vol. 21, pp. 325 - 337

Buluswar, Murli D., Henry Thomson, and Kamal P. Upadhyaya, 1996, "Devaluation and the Trade Blance in India: Stationarity and Cointegration", Applied Economics, Vol. 28, pp. $429-432$

Doroodian, Khosrow, Jung, Chulho, and Roy, Boyd, 1999, "The J-Curve Effect and US Agricultural and Industrial Trade", Applied Economics, Vol. 31, pp. 687 - 695

Enders, Walter, 1995, “Applied Econometric Time Series”, Wiley, New York

Engle, Robert F., David F. Hendry and Jean-Francois Richard, 1983, "Exogeneity", Econometrica, 51, 2, pp. 277 - 304

Ericsson, R. Neil, and John S. Irons, 1994, “Testing Exogeneity”, Oxford University Press

Grunfeld, Y., and Zvi, Griliches, 1960, "Is Aggregation Necessarily Bad?", Review of Economics and Statistics, Vol. 42, pp. 1-13

Gupta-Kapoor, Anju, and Ramakrishnan Uma, 1999, "Is There a J-curve? A New Estimation for Japan”, International Economic Journal, Vol. 13, No. 4, Winter, pp. 71 - 79

Hacker, R. Scott, and Abudlnasser, Hatemi-J, 2002, "The Effect of Real Exchange Rate Changes on Trade Balances in the Short and Long Run: Evidence From German Trade With Transitional European Economies", www.ihh.hj.selersasise2002/papers/ Hacker and\%20Hatermi J Emerging Markets.pdf

Hooper, Peter, Johnson Karen, and Jaime, Marquez, 1998, "Trade Elasticities for G-7 Countries", International Finance Discussion Papers Number 609, Board of Governors of the Federal Reserve System, April

Jung, Chulho, and Khosrow, Doroodian, 1998, "The Persistence of Japan's Trade Surplus", International Economic Journal, Vol. 12, Number 1, Spring 1998

Junz, Helen B., and Rudolf R., Rhomberg, 1973, "Prices and Export Performance of Industrial Countries, 1953 - 63”, American Economic Review, Vol. 63, pp. 412 - 418

Kale, Pelin, 2001, "Turkey's Trade Balance in the Short And The Long Run: Error Correction Modeling and Cointegration", The International Trade Journal, Vol. 1, no. 1 , Spring, pp. 27-55

Kremers, Jeroen J., Neil R. Ericsson, and Juan J. Dolado, 1992, "The Power of Cointegration Tests", Oxford Bulletin of Economics and Statistics, 54, 3 
Marquez, Jaime, 1994, "The Econometrics of Elasticities or the Elasticity of Econometrics: an Empirical Analysis of the Behavior of U.S. Imports", The Review of Economics and Statistics, pp. 471-481

Marquez, Jaime, 1999, "Long-Period Trade Elasticities for Canada, Japan and the United States", Review of International Economics, Vol. 7(1), pp. 102 - 116

Marsh, Ian W., and Stephen P., Tokarick, 1994, "Competitiveness Indicators: A Theoretical and Empirical Assessment", IMF Working Paper, WP/94/29

Marwah, Kanta, and Lawrence R., Klein, 1996, "Estimation of J - Curves: United States and Canada", Canadian Journal of Economics, Vol. 29, No. 3, August, pp. 523 - 539

Meade, E. Ellen, 1988, "Exchange Rates, Adjustment, and The J-Curve", Federal Reserve Bulletin, October

Menon, Jayant, 1995, “Exchange Rate Pass-Through”, Journal of Economic Survey, Vol. 9, No. 2, pp. 197 - 231

Pesaran, Hashem, and Yongcheol, Shin, 1997, "An Autoregressive Distributed Lag Modelling Approach to Cointegration Analysis", DAE Working Papers Amalgamated Series, University of Cambridge

Pesaran, Hashem, Yongcheol, Shin, and Ron J. Smith, 1996, "Testing for the Existence of a Long-Run Relationship", DAE Working Papers Amalgamated Series, no. 9622, University of Cambridge

Rose, Andrew, and Janet L., Yellen, 1989, "Is There a J-curve?", Journal of Monetary economics, 24 , pp. 53-68

Sinha, Dipendra, 2001, "A Note on Trade Elasticities in Asian Countries", International Trade Journal, Vol. 15, No. 2, Summer, pp. 221 - 237

Schwert, G. William, 1989, “Tests for Unit Roots: A Monte Carlo Investigation”, Journal of Business and Economic Statistics, April 1989, Vol. 7 Issue 2, pp. 147 - 160

Upadhyaya, Kamal P., and Dhakal, Dharmendra, 1997, "Devaluation and the Trade Balance: Estimating the Long Run Effect", Applied Economics Letters, Vol. 4, pp. 343 - 345

Urbain, Jean-Pierre, 1992, "On Weak Exogeneity in Error Correction Models", Oxford Bulletin of Economics and Statistics, 54, 2, pp. 187 - 207 
Wilson, Peter, 2001, "Exchange Rates and the Trade Balance for Dynamic Asian Economies - Does the J-Curve Exist for Singapore, Malaysia, and Korea?", Open Economies Review, Vol. 12, pp. 389 - 413

Wilson, William T., 1993, "J-curve Effect and Exchange Rate Pass-Through: An Empirical Investigation of the United States", The International Trade Journal, Vol. 7, No. 4, Summer, pp. 463 - 483 